\title{
Perencanaan Sistem Pembangkit Listrik Hybrid (Panel Surya dan Diesel Generator) Pada Kapal KM.Kelud
}

\author{
Prian Gagani Chamdareno ${ }^{1}$, Eko Nuryanto ${ }^{2}$, Erwin Dermawan ${ }^{3}$ \\ ${ }_{1,2,3)}$ Teknik Elektro Universitas Muhammadiyah Jakarta \\ ${ }^{1,2,3)}$ Jl. Cempaka Putih Tengah 27 no 47 Jakarta 10510 \\ email : prian.gagani@ftumj.ac.id
}

\begin{abstract}
Abstrak
Energi menjadi salah satu isu yang dihadapi oleh Indonesia saat ini bahkan dunia, karena ketidakseimbangan antara ketersediaan energi dengan kebutuhanya. Isu lainnya adalah pemanasan global, dimana Indonesia dalam Konferensi Tingkat Tinggi (KTT) Perubahan Iklim di Paris, Perancis tahun 2015 lalu (COP21) telah berkomitmen untuk menurunkan emisi bersama dengan negara-negara lainnya. Penggunaan bahan bakar fosil sebagai sumber energi saat ini masih menjadi prioritas utama. Akibatnya, kondisi ketersediaan bahan bakar fosil didalam perut bumi akan menjadi semakin cepat menipis. Selain itu, penggunaan bahan bakar fosil merupakan salah satu penyebab global warming dan hujan asam akibat emisi gas yang dihasilkan dan dibuang ke lingkungan. Secara geografis Indonesia terletak diantara dua samedera yaitu Samudra Pasifik dan Samudra Hindia, dan menghubungkan benua Asia dan benua Australia. Indonesia adalah sebuah negara kepulauan berdasarkan konvensi UNCLOS tahun 1982. Indonesia memiliki lebih dari 17 ribu pulau, dengan garis pantai lebih dari $99.000 \mathrm{~km}$, sehingga menjadikan Indonesia sebagai negara dengan garis pantai terpanjang ke dua di dunia setelah Kanada. Indonesia memiliki wilayah laut yang sangat luas, dimana 2/3 dari wilayah negara ini adalah laut. Potensi untuk pembangkit hybrid pada kapal sangatalah menjanjikan. Dengan Sistem pembangkit listrik hybrid (PV dan Generator) ini bertujuan untuk menghemat bahan bakar dan gas buang emisi pada kapal KM.Kelud ketika bersandar di Pelabuhan Tanjung Priok.
\end{abstract}

Kata Kunci: Homer, Hybrid PV dan Generator

\section{PENDAHULUAN}

Sistem pembangkit listrik hybrid (sel surya dan diesel generator) merupakan salah satu alternatif solusi dari dampak negatif sistem pembangkit konvensional pada kapal - kapal di Indonesia. [1]. Energi menjadi salah satu isu yang dihadapi oleh Indonesia saat ini bahkan dunia, karena ketidakseimbangan antara ketersediaan energi dengan kebutuhanya. Isu lainnya adalah pemanasan global, dimana Indonesia dalam Konferensi Tingkat Tinggi (KTT) Perubahan Iklim di Paris, Perancis tahun 2015 lalu (COP21) telah berkomitmen untuk menurunkan emisi bersama dengan negara-negara lainnya. Penggunaan bahan bakar fosil sebagai sumber energi saat ini masih menjadi prioritas utama. Akibatnya, kondisi ketersediaan bahan bakar fosil didalam perut bumi akan menjadi semakin cepat menipis.bakar fosil merupakan salah satu penyebab global warming dan hujan asam akibat emisi gas yang dihasilkan dan dibuang ke lingkungan.

Indonesia memiliki lebih dari 17 ribu pulau, dengan garis pantai lebih dari $99.000 \mathrm{~km}$, sehingga menjadikan Indonesia sebagai negara dengan garis pantai terpanjang ke dua di dunia setelah Kanada. Indonesia memiliki wilayah laut yang sangat luas, dimana $2 / 3$ dari wilayah negara ini adalah laut., Dengan luasnya wilayah laut indonesia maka potensi untuk pembangkit hybrid pada kapal sangatalah menjanjikan. Secara historis, Indonesia dan maritim memang tidak dapat dipisahkan satu sama lain [2]. Indonesia dikenal sebagai negeri seribu pulau dan situasi inilah menyebabkan penyebaran sistem tenaga listrik yang tidak merata disetiap wilayah dan memaksa pulau-pulau terpencil untuk menggunakan generator diesel guna memperoleh sumber daya listrik [3]. Dibandingkan dengan sumber energi lain, energi matahari memiliki banyak keuntungan [4]. Energi matahari harus dikonversi ke energi listrik untuk bisa digunakan pada peralatan [5].

\section{METODE PENELITIAN}


RESISTOR (elektRonika kEndali telekomunikaSI tenaga liSTrik kOmputeR) Vol. 2 No. 1 e-ISSN : 2621-9700, p-ISSN : 2654-2684

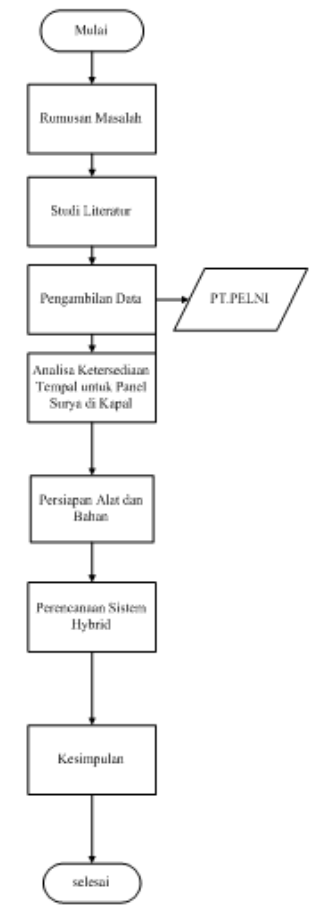

Gambar 1 Diagram alir.

Software HOMER adalah suatu perangkat lunak yang digunakan untuk operasi model system pembangkit listrik skala kecil (micropower), perangkat lunak ini mempermudah evaluasi disain sistem pembangkit listrik untuk berbagai jenis pembangkit listrik skala kecil baik yang tersambung ke jaringan listrik atau pun tidak. Perangkat Lunak ini melakukan perhitungan keseimbangan energi untuk setiap konfigurasi sistem yang akan dipertimbangkan. Kemudian menentukan konfigurasi yang layak, apakah dapat memenuhi kebutuh listridi bawah kondisi yang ditentukan, perkiraan biaya modal, penggantian,operasi dan pemeliharaan, bahan bakar, dan bunga. Kelebihan perangkat lunak ini adalah penggunaannya mudah, bisa mensimulasi, mengoptimasi suatu model kemudian secara otomatis bisa menemukan konfigurasi system optimum yang bisa mensuplai beban dengan biaya sekarang (NPC) terendah, dan bisa menggunakan parameter sensitifitas untuk hasil yang lebih bagus dan akurat.

Data beban listrik yang didapatkan oleh enulis ketika kapal KM.Kelud bersandar di pelabuhan Tantung priok selama pukul 19.00-01.00 WIB.

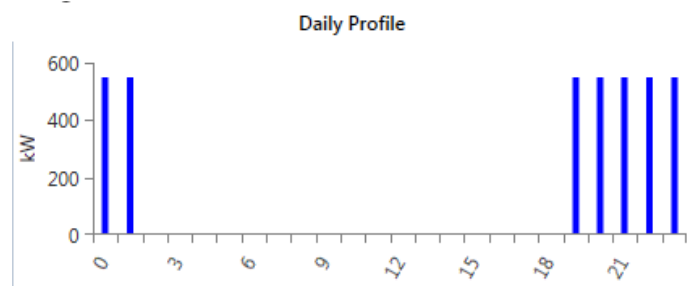

Gambar 2 Grafik beban harian.

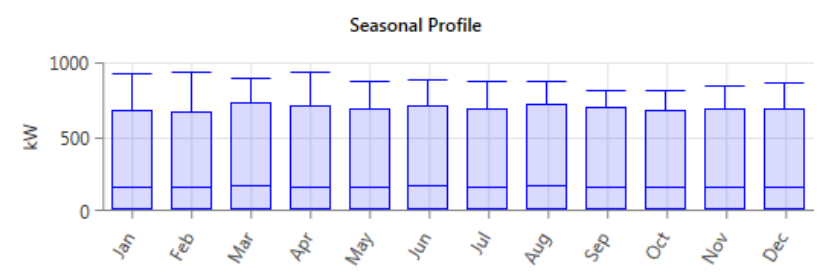

Gambar 3 Grafik beban bulanan.

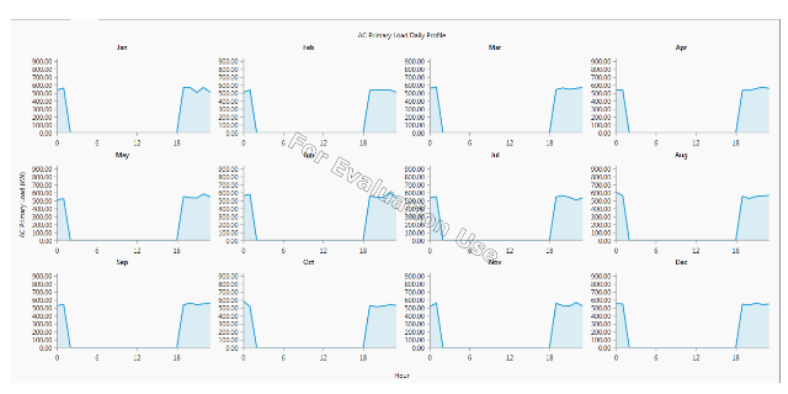

Gambar 4 Grafik beban setahun.

Titik kordinat Pelabuhan Tanjung Priok $\left(6^{\circ} 5.5^{\prime} \mathrm{S}, 106^{0} 53.9^{\prime} \mathrm{E}\right)$ diperoleh dari NASA melalui koneksi internet tentang letak garis lintang dan bujur berdasarkan zona waktu yang telah ada. Data indeks kecerahan rata-rata sebesar 0,484 dan radiasi sinar matahari rata-rata sebesar $4,84 \mathrm{kWh} / \mathrm{m}^{2} /$ day

Tabel 1 Rata-rata radiasi matahari.

Monthly Average Solar Global Horizontal Irradiano
\begin{tabular}{|l|l|l|}
\hline \multicolumn{1}{|c|}{ Month } & $\begin{array}{l}\text { Clearness } \\
\text { Index }\end{array}$ & $\begin{array}{l}\text { Daily Radiation } \\
\text { (kWh/m }{ }^{2} / \text { day) }\end{array}$ \\
\hline January & 0.475 & 4.860 \\
\hline February & 0.471 & 4.950 \\
\hline March & 0.472 & 4.970 \\
\hline April & 0.484 & 4.900 \\
\hline May & 0.487 & 4.620 \\
\hline June & 0.505 & 4.600 \\
\hline July & 0.500 & 4.630 \\
\hline August & 0.496 & 4.860 \\
\hline September & 0.472 & 4.870 \\
\hline October & 0.469 & 4.900 \\
\hline Annual Average (kWh/m & & \\
\hline November & 0.485 & 4.970 \\
\hline December & 0.491 & 4.960 \\
\hline
\end{tabular}


RESISTOR (elektRonika kEndali telekomunikaSI tenaga liSTrik kOmputeR) Vol. 2 No. 1 e-ISSN : 2621-9700, p-ISSN : 2654-2684

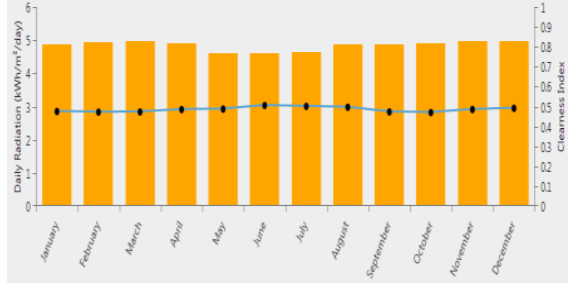

Gambar 5 Indeks kecerahan dan radiasi sinar matahari.

Data kapal KM.Kelud yang didapatkan oleh penulis adalah sebagai berikut:

Panjang Kapal:

$146,50 \mathrm{~m}$

Lebar Kapal:

$23,40 \mathrm{~m}$

Kecepatan: 23,40 knot

Beban Listrik Ketika bersanadar:

$548 \mathrm{kWh}$

Rute Pelayaran:

Tanjung Priok- Pulau Batam - Tanjung Balai Karimum - Belawan

Generator:

4 unit TAIYO $1000 \mathrm{kva}, 800 \mathrm{kw}, 380 \mathrm{v}, 50 \mathrm{~Hz}$

Tabel 2 Potensi Pemasangan Panel Surya.

\begin{tabular}{|l|l|l|l|l|}
\hline Lokasi & $\begin{array}{l}\text { Jumlah } \\
\text { Panel }\end{array}$ & $\begin{array}{l}\text { Daya Panel } \\
\text { (WP) }\end{array}$ & $\begin{array}{l}\text { Total } \\
\text { (WP/jam) }\end{array}$ & $\begin{array}{l}\text { Total } \\
\text { (WP/hari) }\end{array}$ \\
\hline Belakang Cerobong & 88 & 250 & 22.000 & 110.000 \\
\hline Roof top kafe & 96 & 250 & $24.000 t$ & 120.000 \\
\hline Roof top deck 6 & 56 & 250 & 14.000 & 70.000 \\
\hline $\begin{array}{l}\text { Roof top samping kanan } \\
\text { dan kiri deck 6 }\end{array}$ & 78 & 250 & 19.500 & 97.500 \\
\hline Total & 314 & & 78.500 & 397.500 \\
\hline
\end{tabular}

Dengan lama waktu penyinaran matahari di Indonesia rata-rata selama 12 jam dan lama penyiranan maksimum siasumsikan selama 5 jam per hari. Maka daya yang dapat dihasilakan panel surya adalah $392.500 \mathrm{~kW}$ per hari.

Untuk menunjang system hybrid pada kapal KM.Kelud maka diperlukan instalasi system pembangkit listrik hybrid. Secara garis besar ada tiga tipe dari Sistem Hybrid. Yang pertama adalah Series Hybrid System, kedua Parallel Hybrid System, dan ketiga Series Parallel Hybrid System [6].

Tabel 3 Spesifikasi instalasi.

\begin{tabular}{|l|l|l|l|}
\hline No & Nama & Spesifikasi & Jumlah \\
\hline 1 & $\begin{array}{l}\text { Panel Surya Royal } \\
\text { PV Mono 250Wp }\end{array}$ & 314 \\
\hline 2 & $\begin{array}{l}\text { Solar Charge } \\
\text { Controller Deming } \\
480 \mathrm{~V} 200 \mathrm{~A}\end{array}$ & $200 \mathrm{~A}$ & 3 \\
\hline 3 & $\begin{array}{l}\text { Baterai SPRE 12 } \\
225\end{array}$ & $12 \mathrm{~V} \mathrm{225} \mathrm{ah}$ & 150 \\
\hline 4 & $\begin{array}{l}\text { Converter Kaco } \\
\text { XP500U-TL }\end{array}$ & $500 \mathrm{Kw}$ & 1 \\
\hline
\end{tabular}

\section{HASIL DAN PEMBAHASAN}

Dari hasil simulasi dengan menggunakan perangkat lunak HOMER maka diperoleh optimization results dari sistem PLTH diesel generator dan panel surya sebagai berikut.

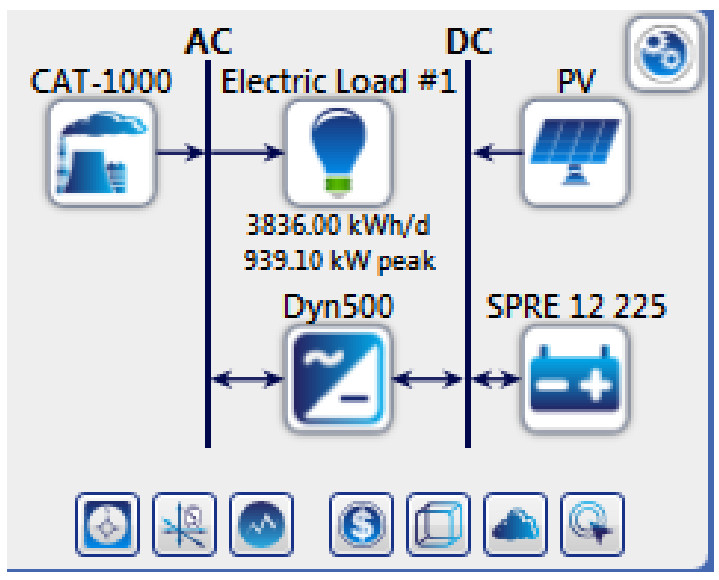

Gambar 6 Rangkaian Hybrid pada Simulasi Homer.

Tabel 4 Hasil dari simulasi.

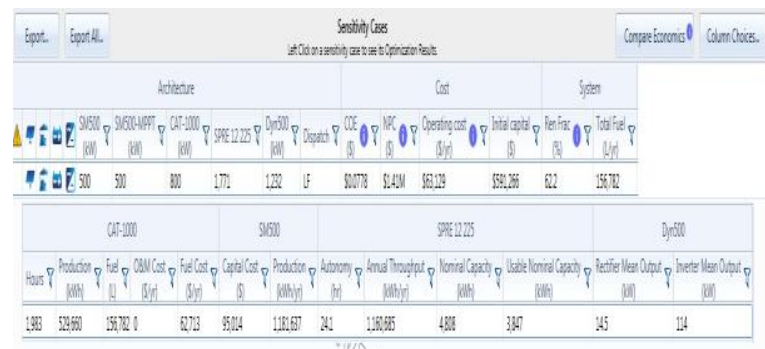

Tabel diatas adalah hasil paling optimization results yang didapatkan dari simulasi HOMER. 
RESISTOR (elektRonika kEndali telekomunikaSI tenaga liSTrik kOmputeR) Vol. 2 No. 1 e-ISSN : 2621-9700, p-ISSN : 2654-2684

Hasil Produksi pada setiap komponenkomponen sebagai berikut:

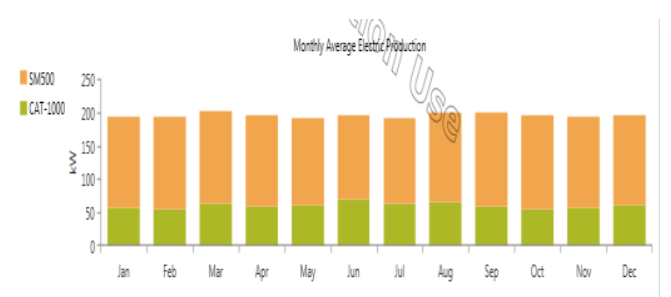

Gambar 7 Grafik Produksi Energi Listrik pada Sistem.

Grafik di atas menunjukkan rata-rata produksi energi listrik masing- masing komponen. Parameter keluaran yang terdapat pada grafik di atas adalah generator (hijau), panel surya (kuning). Total produksi listrik yang dihasilkan oleh sistem panel surya rata-rata pertahun sebesar 1,191,637 $\mathrm{kWh}$.

Excess electricity atau kelebihan listrik yang terdapat pada sistem ini adalah sebesar 14771 $\mathrm{kWh}$ pertahun atau $0,863 \%$. Kelebihan listrik ini adalah selisih total produksi energi listrik selama satu tahun yang dihasilkan oleh sistem dan total beban yang disuplai. Renewable Fraction pada sistem sebesar62.2 \%. Renewable Fraction adalah persentase jumlah energi terbarukan pada sistem.

Tabel 5 Presentasi produksi listrik.

\begin{tabular}{|l|l|l|}
\hline Nama Item & kWh/tahun & $\%$ \\
\hline PV & $1,181,637$ & 69.0 \\
\hline Generator & 529,660 & 31.0 \\
\hline Total & $1,711,297$ & 100 \\
\hline
\end{tabular}

Daya nominal Generator adalah sebesar 200 $\mathrm{kW}$ dengan total produksi energi pertahun sebesar $529.660 \mathrm{kWh}$. Generator dirancang untuk menyupali beban dan sebagian beban dilayani oleh energi angin atau surya [7]. Generator set di kapal menjadi tenaga utama yang mencukupi kebutuhan listrik pada kapal [8].

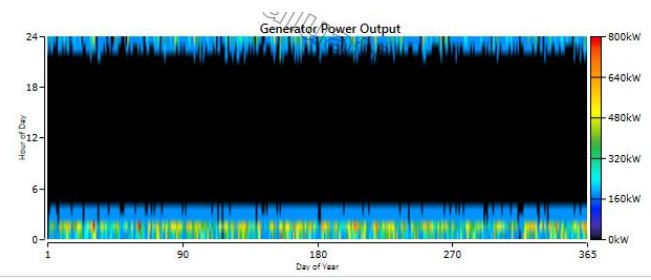

Gambar 8 Daya yang dihasilkan Generator.
Gambar diatas merupakan Daya yang dihasilkan Generator yang terjadi selama setahun yang terjadi dalam rentang waktu 24 jam dengan hasil simulasi yang menunjukkan bahwa daya output sebesar $200 \mathrm{~kW}$ dengan total produksi energi pertahun sebesar $529.660 \mathrm{kWh}$.

Tabel 6 Parameter keluaran Generator.

\begin{tabular}{|c|c|l|}
\hline Quantty & Value & Unts \\
\hline Mean Output & 267 & $\mathrm{~kW}$ \\
\hline Capacity Factor & 7,56 & $\%$ \\
\hline Total Production & 529,660 & $\mathrm{kWh} /$ tahun \\
\hline Minimum Output & 200 & $\mathrm{~kW}$ \\
\hline Maximum Output & 800 & $\mathrm{~kW}$ \\
\hline Hours of Operation & 1.983 & $\mathrm{jam} / \mathrm{tahun}$ \\
\hline
\end{tabular}

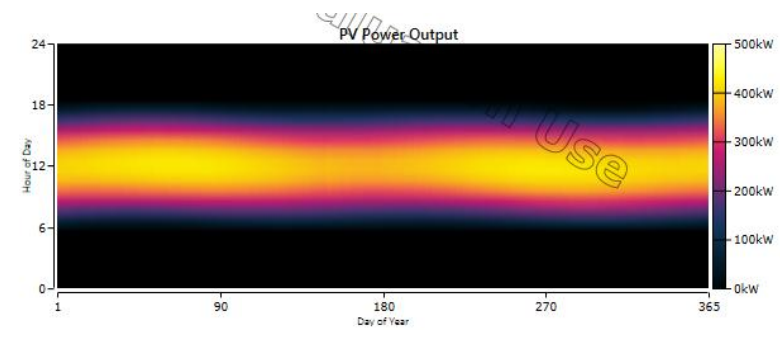

Gambar 9 Daya yang dihasilkan PV

PV hanya dapat bekerja pada saat ada radiasi matahari [9]. Gambar diatas merupakan Daya yang dihasilkan oleh PV yang terjadi selama setahun yang terjadi dalam rentang waktu 24 jam dengan hasil simulasi yang menunjukkan bahwa daya output akan maksimal pada pukul 10.00-15.00 dengan total produksi energi pertahun sebesar 1,181,637 kWh/tahun. Shunt controller juga memiliki blocking diode untuk menghindari arus dari arus balik dari baterai ke solar cells pada malam hari [10].

Tabel 7 Parameter keluaran Panel Surya. 
RESISTOR (elektRonika kEndali telekomunikaSI tenaga liSTrik kOmputeR) Vol. 2 No. 1 e-ISSN : 2621-9700, p-ISSN : 2654-2684

\begin{tabular}{|c|c|c|}
\hline Quantity & Value & Units \\
\hline Mean Output & 135 & $\mathrm{~kW}$ \\
\hline Mean Output & 3,237 & $\mathrm{kWh} / \mathrm{hari}$ \\
\hline Capacity Factor & 27,0 & $\%$ \\
\hline Total Production & $1,181,63$ & $\mathrm{kWh} / \mathrm{tahun}$ \\
\hline Minimum Output & 0 & $\mathrm{~kW}$ \\
\hline Maximum Output & 429 & $\mathrm{~kW}$ \\
\hline PVPenetration & 84,4 & $\%$ \\
\hline Hours of Operation & 4.406 & $\mathrm{jam} / \mathrm{tahun}$ \\
\hline
\end{tabular}

\begin{tabular}{|l|l|l|}
\hline \multicolumn{1}{|c|}{ Quantity } & \multicolumn{1}{c|}{ Value } & \multicolumn{1}{c|}{ Units } \\
\hline Carbon Dioxide & 414.353 & $\mathrm{~kg} / \mathrm{yr}$ \\
\hline Carbon Monoxide & 281 & $\mathrm{~kg} / \mathrm{yr}$ \\
\hline $\begin{array}{l}\text { Unburned } \\
\text { Hydrocarbons }\end{array}$ & 9.41 & $\mathrm{~kg} / \mathrm{yr}$ \\
\hline Particulate Matter & 18.8 & $\mathrm{~kg} / \mathrm{yr}$ \\
\hline Sulfur Dioxide & 1.028 & $\mathrm{~kg} / \mathrm{yr}$ \\
\hline Nitrogen Oxide & 2.643 & $\mathrm{~kg} / \mathrm{yr}$ \\
\hline
\end{tabular}

Tabel 11 Parameter Gas Buang (emisi) (NoHybrid).

Dari hasil simulasi yang dilakukan kepada kedua konfigurasi sistem, maka didapatkan perbandingan dari parameter yang telah ditentukan

Tabel 8 Parameter Konsumsi Bahan Bakar (Hybrid)

\begin{tabular}{|l|l|l|}
\hline \multicolumn{1}{|c|}{ Quantity } & \multicolumn{1}{c|}{ Value } & \multicolumn{1}{c|}{ Units } \\
\hline Total fuel consumed & 156.782 & L \\
\hline Avg fuel per day & 430 & L/day \\
\hline Avg fuel per hour & 17.9 & L/hour \\
\hline
\end{tabular}

Tabel 9 Parameter Konsumsi Bahan Bakar (NonHybrid).

\begin{tabular}{|l|l|l|}
\hline \multicolumn{1}{|c|}{ Quantity } & \multicolumn{1}{c|}{ Value } & \multicolumn{1}{c|}{ Units } \\
\hline Total fuel consumed & 763.221 & L \\
\hline Avg fuel per day & 2.091 & L/day \\
\hline Avg fuel per hour & 87.1 & L/hour \\
\hline
\end{tabular}
adalah:

Maka persentase penurunan bahan bakar

$156,782: 763,221 \times 100 \%=20,5$ atau $20,5 \%$

Dari hasil simulasi yang dilakukan kepada kedua konfigurasi sistem, maka didapatkan perbandingan dari parameter yang telah ditentukan

Tabel 10 Parameter Gas Buang (emisi) (Hybrid).

\begin{tabular}{|l|l|l|}
\hline \multicolumn{1}{|c|}{ Quantity } & \multicolumn{1}{c|}{ Value } & \multicolumn{1}{c|}{ Units } \\
\hline Carbon Dioxide & 2.017 .087 & $\mathrm{~kg} / \mathrm{yr}$ \\
\hline Carbon Monoxide & 1.366 & $\mathrm{~kg} / \mathrm{yr}$ \\
\hline $\begin{array}{l}\text { Unburned } \\
\text { Hydrocarbons }\end{array}$ & 45.8 & $\mathrm{~kg} / \mathrm{yr}$ \\
\hline Particulate Matter & 91.6 & $\mathrm{~kg} / \mathrm{yr}$ \\
\hline Sulfur Dioxide & 5.006 & $\mathrm{~kg} / \mathrm{yr}$ \\
\hline Nitrogen Oxide & 12.868 & $\mathrm{~kg} / \mathrm{yr}$ \\
\hline
\end{tabular}

Maka Parameter Penurunan emisi adalah: $414.353: 2.017 .087 \times 100 \%=20,5$ atau $20,5 \%$

\section{KESIMPULAN}

Hasil analisis yang telah dilakukan pada software HOMER, dapat diambil kesimpulan bahwa total produksi listrik yang di hasilkan pada system hybrid PLTD-PLTS pertahun yaitu sebesar 1,711,297 kWh/tahun. Dimana kontribusi PLTS terhadap sistem PLTH sebesar $69.0 \%$ atau 1,181,637 kWh/tahun. Sedangkan PLTD $31.0 \%$ atau $529,660 \mathrm{kWh} /$ tahun. Kelebihan energinya selama setahun sebesar $14.771 \mathrm{kWh} /$ tahun.

Dampak lingkungan dapat dikurangi dengan menerapkan sistem PLTD-PLTS. Emisi $\mathrm{CO}^{2}$ yang dihasilkan pada sistem ini adalah sebesar 414.353 $\mathrm{kg} /$ tahun, sedangkan ketika tidak menerapkan sistem hybrid Gas emisi adalah sebesar 2.017.087 kg/tahun terjadi penurunan jumlah emisi $\mathrm{CO}^{2}$ sebesar 1.602.734 kg/tahun atau turun sebesar 20,5\%.

Dengan menerapkan sistem PLTD-PLTS maka konsumsi bahan bakar dapat dihemat. Bahan bakar yang dapat dihemat adalah sebesar $156.782 \mathrm{~L}$ sedangkan konsumsi bahan bakar sebelum menerapkan sistem PLTD-PLTS adalah sebesar 763.221 $\mathrm{L}$ atau hemat sebesar $20,5 \%$.

Sistem hybrid ini memiliki nilai NPC \$ 1.407.361.00, biaya listrik $\$ 0.07776$ per $\mathrm{kWh}$, Biaya operasi $\$ 63.128 .53$

Diharapan perkembangan dunia perkapalan dapat berkembang dengan system terbarukan hybrid tidak hanya mengutamakan bahan bakar fosil. Penelitian ini masih jauh dari kata sempurna oleh sebab itu penulis mengharapkan penelitian ini 
RESISTOR (elektRonika kEndali telekomunikaSI tenaga liSTrik kOmputeR) Vol. 2 No. 1 e-ISSN : 2621-9700, p-ISSN : 2654-2684

dikembangkan lagi secara mendalam dengan kajian yang lebih lengkap.

\section{DAFTAR PUSTAKA}

[1] D. P. Putri and E. S. Koenhardono, "Perencanaan Sistem Pembangkit Listrik Hybrid (Sel Surya dan Diesel Generator) Pada Kapal Tanker," Jurnal Teknik ITS, vol. 5, no. 2, pp. B394-B399, 2016.

[2] "Refleksi Indonesia Sebagai Negara Maritim | GEOTIMES." [Online]. Available: https://geotimes.co.id/opini/refleksi-indonesiasebagai-negara-maritim/. [Accessed: 31-Mar2019].

[3] I. T. Utomo, "Studi analisis pembangkit listrik hybrid (diesel-angin) di pulau karimun jawa," jurnal mahasiswa teub, vol. 2, no. 5, 2014.

[4] B. Budiyanto and F. Fadliondi, "The Improvement of Solar Cell Output Power Using Cooling and Reflection from Mirror," International Journal of Power Electronics and Drive Systems (IJPEDS), vol. 8, no. 3, p. 1320, Sep. 2017.

[5] F. Fadliondi, H. Isyanto, and B. Budiyanto, "Bypass Diodes for Improving Solar Panel Performance," International Journal of Electrical and Computer Engineering (IJECE), vol. 8, no. 5, p. 2703, Oct. 2018.

[6] "3 Sistem Hybrid Pada Mobil.”.

[7] P. G. Chamdareno and H. Hilal, "Analisa Pembangkit Listrik Tenaga Hybrid PLTDPLTS di Pulau Tunda Serang Banten," RESISTOR (elektRonika kEndali telekomunikaSI tenaga liSTrik kOmputeR), vol. 1, no. 1, 2018.

[8] R. H. B. I. Purba, E. S. Hadi, and U. Budiarto, "ANALISIS OPTIMASI PENENTUAN KAPASITAS DAYA GENERATOR PADA KAPAL KM. SINABUNG," Jurnal Teknik Perkapalan, vol. 3, no. 2, 2015.

[9] S. Soedibyo and D. Hendrawati, "DESAIN SISTEM HIBRID PHOTOVOLTAICBATERAI MENGGUNAKAN BIDIRECTIONAL SWITCH UNTUK CATU DAYA KELISTRIKAN RUMAH TANGGA 900VA, 220 VOLT, 50 HZ," Prosiding SNST Fakultas Teknik, vol. 1, no. 1, 2016.

[10] “Jenis Solar Charge Controller Regulator." . 